Sains Malaysiana 49(1)(2020): 113-119

http://dx.doi.org/10.17576/jsm-2020-4901-13

\title{
Photoreceptor Therapy: Generation of Neurosphere-Like Cells from Human Mesenchymal Stem Cells Expressing Erythropoietin
}

(Terapi Fotoreceptor: Generasi Sel Seperti Sfera Neuro daripada Sel Stem Mesenkima Manusia Ekspresi Eritropoletin)

\author{
Mok Pooi Ling*, Shirley Ding Suet Lee, Aisha Farhana, Badr Alzahrani, Mohammed Safwan Ali \\ KHAN \& SURESH KumaR*
}

\section{ABSTRACT}

The loss of photoreceptors is a major concern implicated in age-macular degeneration (AMD), a type of neurodegenerative disorder. Failure to prescribe a suitable treatment due to the lack of understanding of the molecular pathogenesis, and limited capacity to compensate irreparably damaged photoreceptors in the retina have greatly contributed to the progression of visual dysfunction. Our previous study has shown that Mesenchymal Stem Cells (MSCs) expressing erythropoietin (EPO) could commit into photoreceptor cell lineage. However, the efficiency of cell differentiation is limited. The present study aims to explore the capacity of these MSCs to form neurospheres. The cells were transduced with lentiviral particles encoding for human EPO and green fluorescent protein (GFP) genes, culture-expanded and sorted before subjected for differentiation induction into neural precursor cells. Our results showed that MSC-EPO developed into larger neurosphere and expressed relatively higher expression of nestin compared with MSCs alone when cultured under neural induction medium. These preliminary findings suggested that MSC-EPO have greater neurogenic potential than MSCs alone. Further study is needed to evaluate the possibilities of neurosphere to delete differentiate into functional photoreceptor cells. We believe that the success of neurosphere expansion may potentially be useful in scaling up the manufacturing of photoreceptors in a shorter time and at an efficient cost for retinal cell replacement therapy.

Keywords: Erythropoietin; mesenchymal stem cells; neural differentiation; neurosphere; photoreceptor

\section{ABSTRAK}

Kehilangan fotoreseptor menjadi kebimbangan utama dalam degenerasi makro-usia (AMD), sejenis gangguan neurodegeneratif. Perkembangan disfungsi visual berlaku apabila terdapat kegagalan untuk memberi rawatan yang sesuai akibat kekurangan pemahaman dalam patogenesis molekul dan keupayaan terhad untuk mengganti kerosakan fotoreseptor di retina. Kajian terdahulu menunjukkan bahawa Sel Stem Mesenkima (MSC) yang mengungkapkan eritropoletin (EPO) boleh berkembang menjadi sel berketurunanan fotoreseptor. Walau bagaimanapun, kecekapan pembezaan sel adalah terhad. Kajian ini bertujuan untuk meneroka keupayaan MSCs untuk membentuk sfera neuro. Sel telah ditransduksi dengan zarah lentiviral yang mengekod gen manusia protein EPO dan hijau neon (GFP), diperbanyakkan melalui pengkulturan sel dan ditulen sebelum induksi diferensiasi ke sel prekursor saraf. Keputusan kami menunjukkan bahawa MSC-EPO berkembang menjadi sfera neuro yang lebih besar dan menunjukkan ekspresi nestin yang lebih tinggi berbanding dengan MSC sahaja apabila dikultur di dalam medium induksi saraf. Penemuan awal ini mencadangkan bahawa MSC-EPO mempunyai potensi neurogen yang lebih besar daripada MSC sahaja. Kajian lanjut diperlukan untuk menilai kebolehan sfera neuro untuk membeza seterusnya kepada sel-sel fotoreseptor yang berfungsi. Kami percaya bahawa kejayaan pengembangan sfera neuro berpotensi digunakan untuk meningkatkan produksi fotoreseptor dalam masa yang lebih singkat dan pada kos yang cekap untuk terapi penggantian sel retina.

Kata kunci: Eritropoletin; fotoreseptor; pembezaan neural; sel stem mesenkima; sfera neuro

\section{INTRODUCTION}

A permanent loss of neurons is a common pathology observed in the late-onset of multiple irreversible conditions in neurodegenerative diseases including Alzheimer's disease (Ding et al. 2011), Parkinson's disease (Wyse et al. 2014), multiple sclerosis (Borhani Haghighi et al. 2012) and age-macular degeneration (AMD) (Schwartz et al. 2016). Despite the increase in lifespan of global population due to advances in the provision of medical healthcare, there is a lack of efficient treatments that could halt or delay the progression of these diseases. Our body possess limited capability to regenerate new neuronal cells (Klassen 2015). Hence, the idea to replace or repair destructive neurons by use of stem cells replacement therapy is rational.

Tremendous works have been dedicated to research into possible use of Mesenchymal Stem Cells (MSCs) for countering visual loss in the elderly due to AMD(Ding et 
al. 2019a; Mok et al. 2017). MSCs represents a reliable cell source that has multipotent differentiation potential, within and beyond its mesodermal lineage, to form different cell types. In our previous studies, we showed that when MSCs were transplanted into a transgenic rat model that exhibit retina degeneration, some of these cells formed retina neuronal cells (Leow et al. 2015). In an in vitro study, we showed that these cells could be better coaxed into retinal photoreceptor cells when introduced with erythropoietin (EPO) gene (Ding et al. 2019a). Similar to other studies that demonstrated successful MSC differentiation into other neuronal cells (Danielyan et al. 2009; Hayashi 2013; Roozafzoon et al. 2015), the limited photoreceptor cell yield remains one major obstacle in achieving sufficient visual function improvement.

Hence, the current study is a follow-up initiative to find methods to upscale the production of photoreceptors in the laboratory (Ding et al. 2019a). Instead of direct differentiation, we hypothesized that MSC-EPO could be differentiated into neurosphere before further induction to produce larger number of photoreptors. To do this, we incubated MSC-EPO in a specific neurogenic differentiation culture medium and determined its potential ability to form neurospheres. The EPO gene was transduced along with green fluorescence protein (GFP) reporter gene into the MSCs which were derived from human Wharton's Jelly (hWJ-MSCs). The results demonstrated that the transduced hWJ-MSCs could form larger neurosphere and expressed relatively more intense nestin marker compared with nontransduced cells. This study is important to provide experimental foundation for application of MSC expressing EPO to efficiently generate neural progenitor cells, helpful in upscaling the manufacturing of photoreceptor cells in the future.

\section{Materials AND Methods}

\section{CELL CULTURE AND CHARACTERIZATION OF MSC-EPO}

The MSCs used in this experiment were derived from human Wharton's Jelly, a gift from Cryocord Sdn. Bhd. (Malaysia) in the form of cryovial, with written, informed consent from patient donors. The cells were cultureexpanded and characterized as described in previous publications from our laboratory (Ding et al. 2019a). These cells were then transduced by lentiviral particles encoding $E P O$ gene according to a procedure mentioned in a prior report (Ding et al. 2019a). The transduced cells were cryopreserved in liquid nitrogen at $-180^{\circ} \mathrm{C}$ until used for further experiments.

\section{SPONTANEOUS DIFFERENTIATION OF NEUROSPHERES FROM MSCS AND EPO-EXPRESSING MSCS}

Prior to neurosphere differentiation experiment, the transduced MSC-EPO cells were purified by two to three rounds of passaging and sorting by using a flow cytometer sorter (BD FACSAria III) (BD Biosciences). The transduced MSC-EPO cells were then cultured in single cell suspension at a seeding concentration of $5 \times 10^{5}$ cells $/ \mathrm{cm}^{2}$ in a $10 \mathrm{~cm}$ sterile low adherence petri dish (Fisher Scientific) containing $5 \mathrm{~mL}$ of neural induction medium. The neural induction medium was prepared by supplementing $1 \times$ Glasgow Minimum Essential medium (GMEM; Gibco) with $2.3 \%$ sodium bicarbonate, $1 \mathrm{mM}$ of L-glutamine (Gibco), $0.5 \mathrm{mM}$ of sodium pyruvate (Gibco), 1× nonessential amino acids (NEAA; Gibco), $0.1 \mathrm{mM}$ of $\beta$-mercaptoethanol (Gibco), and 15\% heat-inactivated FBS (Gibco). Two $\mathrm{mL}$ of fresh neural induction medium was added to the cultured cells in every three alternating day. Following incubation at approximately 8 days, the floating cell aggregates were collected using a Pasteur pipette. The aggregates were then transferred into a gelatin pre-coated 24-well plate for immunocytochemical staining. Prior to that, the gelatin-coated plates were prepared by the addition of $300 \mu \mathrm{L}$ of gelatin solution at $0.1 \%$ into each well and incubated at $25^{\circ} \mathrm{C}$ for $2 \mathrm{~h}$. Following incubation, coating solution was discarded and the wells were washed gently with $1 \times$ of sterile PBS for twice. The coated plates were sealed with Parafilm and kept at $4{ }^{\circ} \mathrm{C}$ until identification of neurosphere aggregates by immunocytochemical staining.

\section{IMMUNOCYTOCHEMICAL STAINING OF DIFFERENTIATED MSCS AND EPO-EXPRESSING MSCS}

The differentiation potential of MSCs and MSC-EPO into neural precursor cells in the neurospheres was assessed by immunocytochemical staining with primary antibodies specific for neural precursor cell marker, nestin. Briefly, the supernatant of MSC culture medium was discarded and cells were washed three times with $1 \times$ sterile PBS before fixation by $4 \%$ paraformaldehyde $\mathrm{pH} 7.4$ (Sigma) at $25^{\circ} \mathrm{C}$ for $15 \mathrm{~min}$. After that, the fixative was aspirated and the cells were washed three times with cold sterile PBS in $0.1 \%$ Tween 20 (PBST). The cells were then incubated with $0.1 \%$ Triton X-100 in PBS for 10 min to permeablize the cells. Then, the cells were washed three times in $0.1 \%$ PBST solution before blocking by incubation with $1 \%$ BSA blocking buffer in $0.1 \%$ PBST for $30 \mathrm{~min}$.

After removal of blocking buffer, spherical cell aggregates were stained with mouse monoclonal anti-nestin primary antibody (Millipore; $1: 200$ ) for $16 \mathrm{~h}$, in $4^{\circ} \mathrm{C}$ chiller. The staining solution was prepared freshly by diluting 6 $\mu \mathrm{L}$ of primary antibody nestin in $1 \%$ BSA blocking buffer to a final volume of $1.2 \mathrm{~mL}$ and each well was filled to a final volume of $300 \mu \mathrm{L}$ containing diluted anti-nestin antibody. Following incubation, the cells were washed several times in $0.1 \%$ PBST solution and conjugated with secondary antibody Alexa Fluor 594 goat anti-mouse IgG (Merck Millipore; Darmstadt, Germany) in 1\% BSA blocking buffer at 1:400 dilution. The plate was covered with aluminium foil for $1 \mathrm{~h}$ at $25^{\circ} \mathrm{C}$, followed by, repeated washing in $0.1 \%$ PBST buffer solution for 3 times. Lastly, $4 \%$ paraformaldehyde fixative solution was added to the cells for microscopic examination under inverted 
fluorescence microscope. The intensity of nestin expression on the cell clusters was measured by ImageJ software (National Institute of Health; USA) after normalization with DAPI stain. The mean expressions of nestin in the cell clusters derived from both unmodified MSCs and MSC-EPO were then compared, and its significant difference was determined by unpaired T-test using Prism 5.0 (GraphPad).

\section{RESUlTS AND DisCUSSION}

Mesenchymal stem cells (MSCs) has emerged as a suitable choice for replacement of retinal cells, particularly the photoreceptors (Leow et al. 2015) and retinal pigmented epithelial cells (Alsaeedi et al. 2019), which are highly affected in AMD progression (Bhutto \& Lutty 2012). Despite many reported methods to generate photoreceptors in vitro or direct cell transplantations (Ding et al. 2017), achievement of treatment outcomes remained far from ideal. One of the challenges has been the low differentiated cell yield, as observed from in vitro works.

In our previous study, we have evinced that introduction of EPO could significantly increase the differentiation of MSCs into photoreceptors (Ding et al. 2019b). The MSCs were derived from human Wharton's Jelly and characterized by using flow cytometry in prior(Ding et al. 2019b). MSCs population showed high expression for CD90, CD73, CD105, CD29, and HLA-ABC but largely negative for marker of haematopoietic cells including CD34, CD14, CD45, CD80, and CD86 (Ding et al. 2019b). Established cultures of MSCs at third passage were culture-expanded for subsequent transduction experiments with lentivirus vector encoding the human EPO and GFP reporter genes. The transduced cells were culture-expanded and the expression of GFP was monitored by a fluorescence microscope. Meanwhile, the flow cytometer indicated $13.0 \%$ of the cells exhibited green fluorescence. Prior to neurosphere differentiation, the transduced cells (GFP+ cells) were purified by using a flow cytometer sorter (Figure 1).

Neurospheres are neural progenitor cells which can undergo fate specification to form other type of mature retinal neuronal cells (Chung et al. 2013; Ji et al. 2017; Leite et al. 2014; Ma et al. 2011; Mung et al. 2016; Yang et al. 2015), important for phototransduction. Various cell culture techniques have been adopted to ensure a close physiological resemblance that may influence neuronal cell fate and differentiation (Gupta et al. 2016). Among all cell culture systems, MSCs cultured as floating spherical aggregates referred as neurospheres were found to direct into neural cell lineage effectively when compared to conventional culture method (Portmann-Lanz et al. 2010; Zhou et al. 2016). Coupled with the induced expression of EPO, this technique may serve as a potential strategy to increase the yield of neurospheres and ensure survivability of cells upon transplantation in a patient. Additionally, the advantage of differentiation into neurospheres also lies on its potential to be expanded before subjected to further induction into terminally differentiated cells, hence, increasing production of photoreceptor cell yield.

With reference to a protocol reported previously (MunFun et al. 2015) and with slight modifications, we found that the MSCs and MSC-EPO in suspension culture were capable of developing into clusters of neurosphere (Figure 2). MSCs and MSC-EPO were analysed for their neural differentiation potential by culturing sorted cells for eight days to form neurosphere in suspension. During neural induction, morphological changes in MSCs and MSC-EPO cultures were captured as two-dimensional microscopic images at different time points (Figure 2). Cultured cells propagated into a small, floating-clustered cell with irregular edges, while cells that failed to form cluster died and sediment on the bottom of the culture plate two days

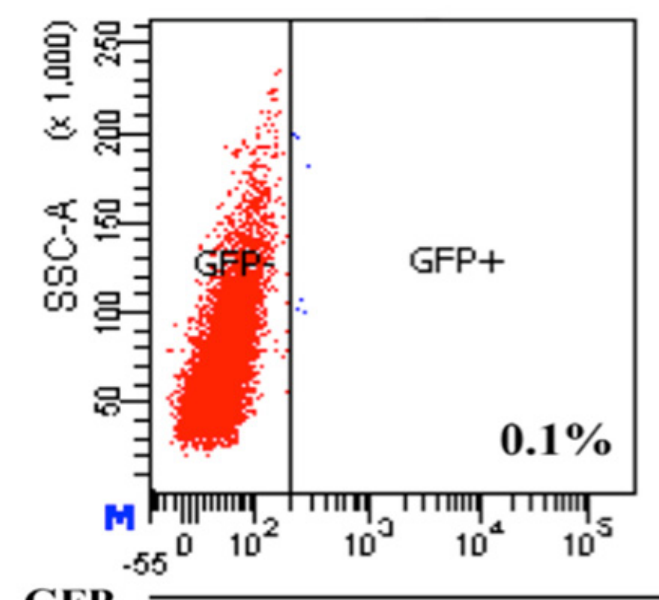

Non-transduced MSC

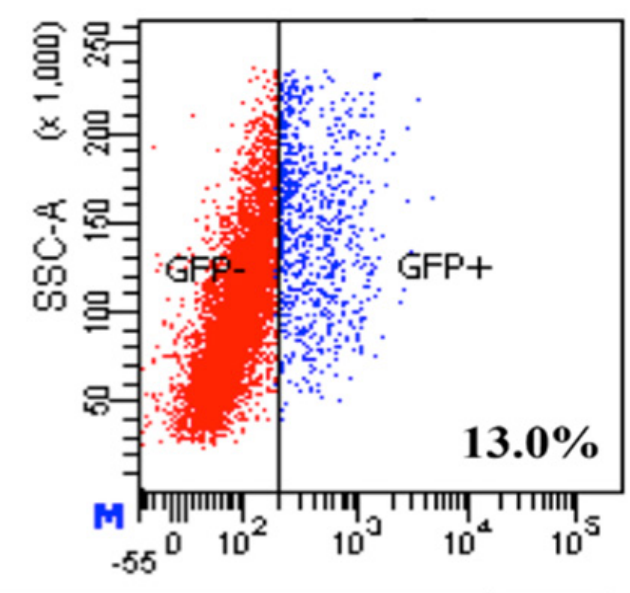

EPO-transduced MSC

FIGURE 1. Flow cytometry data representing transduction efficacy of non-transduced (red plot) and EPO-transduced (blue plot) MSCs based on the GFP+ intensity in each gated MSC population from the non-transduced MSCs (GFP-). Data are representative of four independent transduction experiments. An isotype control was employed in the experiment to eliminate background fluorescence. The GFP+ cells were sorted for downstream experiment to induce neurosphere formation 

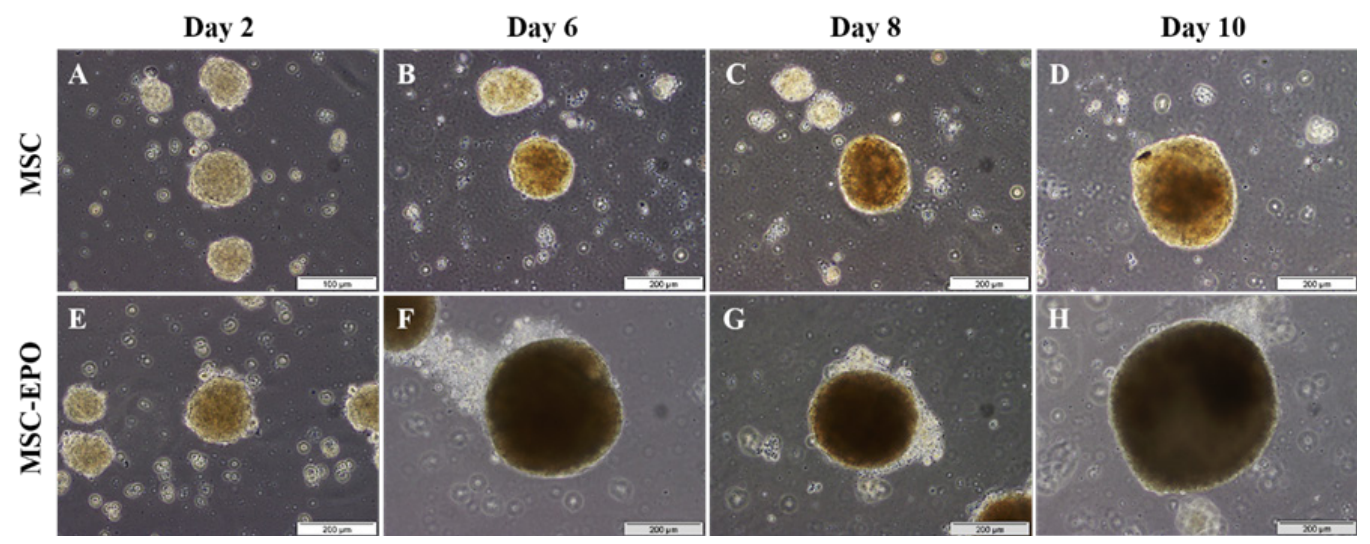

FIGURE 2. Morphological changes in neurosphere-derived from MSCs and MSC-EPO following to neural differentiation after 10 days, in vitro. A time-point discrimination of neurosphere-like cell aggregates derived from MSCs and MSC-EPO were assessed on day $2,6,8$, and 10, after initial cell plating. Note that floating sphere cultures formed a smooth edge with darkened centre, after 6 to 8 days. Cells were imaged by phase-contrast microscopy at $\times 100$ magnifications (scale bar, $200 \mu \mathrm{m}$ )

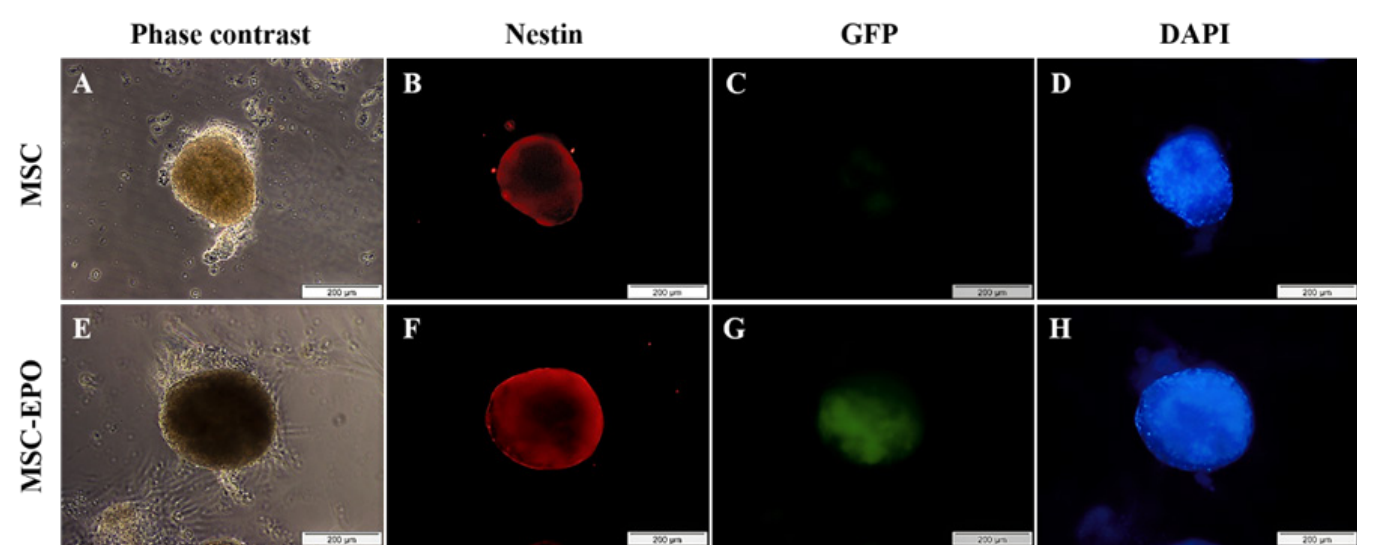

FIGURE 3. Characterization of neurosphere-like aggregates cultured from MSCs and MSC-EPO after neural differentiation at day 10. Morphological feature of neurosphere-like aggregates derived from MSCs (A) and MSC-EPO (E), respectively, after cell plating onto gelatin-coated plate. Both neurosphere-like aggregates were immunopositive for neural progenitor cell marker, nestin (red) (B $\&$ F). GFP expression (green) was only detected in neurosphere derived from MSC-EPO (G). Cell aggregates were counterstained with nuclear DAPI staining (blue) for cell nuclei localisation (D \& H). Cells were imaged by fluorescence microscopy at $\times 100$ magnifications (scale bar, $200 \mu \mathrm{m}$ )

after initial cell plating (Figure 2). The spherical cellular aggregates showed various sizes, ranging from $150 \mu \mathrm{m}$ to $230 \mu \mathrm{m}$ for MSCs and from $180 \mu \mathrm{m}$ to $400 \mu \mathrm{m}$ for MSCEPO. Some of the neurospheres formed from MSC-EPO showed appearance of groups of cells at the boundary. After 8 to 10 days of neural induction, the neurospheres showed well-defined boundary around the edge and exhibited dark core in the centre (Figure 2(G) and Figure 2(H)).

From the immunocytochemical analysis in Figure 3, the expression of nestin, an early neural progenitor cell marker, were detected in aggregates formed by MSC-EPO and MSCs. This indicates that transduction did not hamper differentiation of MSCs into neural progenitor. Furthermore, neurospheres formed from MSC-EPO constitutively expressed GFP (Figure 3(G)) suggesting that the neural differentiation of MSC-EPO did not affect the EPO gene expression. Also, neurosphere-derived from MSC-EPO appeared larger in size and exhibited significantly higher expression $(p<0.01)$ for neural stem or progenitor marker, nestin, as compared with those derived from unmodified MSCs (Figure 3(F) \& 3(B)).

The disparity between the neurospheres formed between MSCs and MSC-EPO was most likely due to the release of secretory EPO protein from MSC-EPO (Figure $3)$. It is noteworthy that EPO has long been recognized to also participate in neurogenesis and anti-apoptotic activities (Eckardt \& Kurtz 2005; Lv et al. 2015; Zhang et al. 2007) to maintain various tissue functions (Chung et al. 2009; Shirley Ding et al. 2016). For example, EPO was found to be released in an autocrine manner from neural progenitor cells in a mouse model of spinal cord injury to sustain neural progenitor cell survivability under apoptotic microenvironment and upregulate neurogenesis (Carelli et al. 2016). Meanwhile, administration of EPO were demonstrated to increase precursor and mature neuronal cell differentiation in healthy young mouse models (Hassouna et al. 2016). Therefore, the larger spherical cell aggregates derived from MSC-EPO could be attributed to 


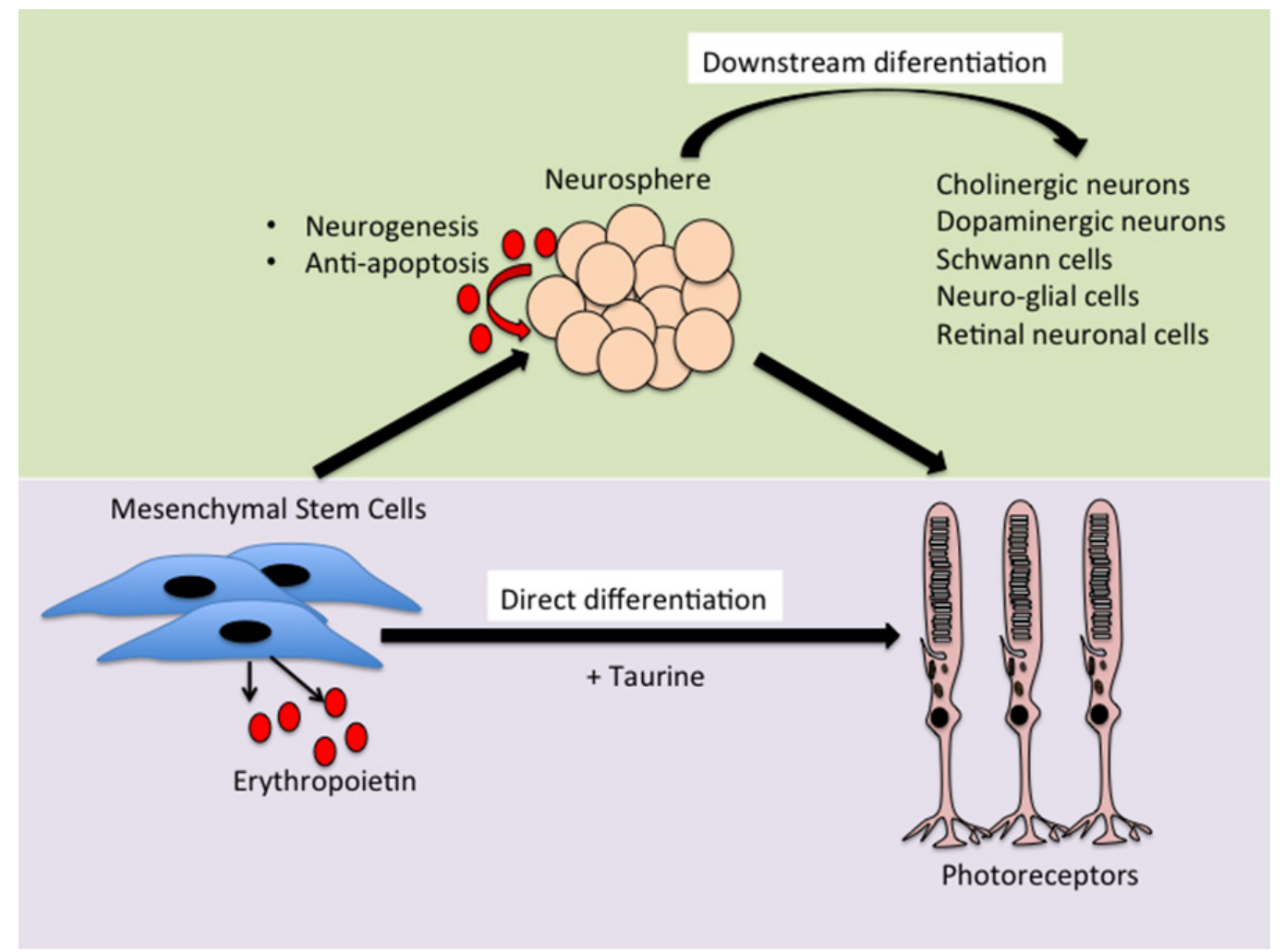

FIGURE 4. Comparison of differentiation methods using Mesenchymal Stem Cells (MSCs) expressing erythropoietin (MSC-

EPO) into photoreceptors. Direct differentiation can generate photoreceptors with limited yield. By inducing MSC-EPO to

form neurospheres, a type of neural progenitor cell, the production of photoreceptors can be largely upscaled. In addition, the neurospheres can be expanded and cryopreserved until further downstream differentiation to form other types of neuronal cells, e.g. cholinergic- or dopaminergic neurons, Schwann cells, neuro-glial cells, or other retinal neuronal cells. Erythopoietin has important role in promoting neurogeneis and anti-apoptosis

both enhanced neural differentiation and anti-apoptotic properties of EPO.

In the context of visual function repair, this study provided experimental foundation for application of MSC expressing EPO to efficiently generate neural progenitor cells, potentially helpful in upscaling the manufacturing of photoreceptor or other cell types such as RPE or ganglion cells in the future. More studies are needed to affirm these. Quantitative data are important to observe the changes of specific mRNA gene expression during development or maturation of these cell types, and to allow further optimization of cell production (OvandoRoche et al. 2018). Also, functional studies using animal models will be needed to shed light on the state of cell integration in neural circuits. Noteworthy of mentioning is these neurospheres can be used for directed differentiation into cholinergic- (Danielyan et al. 2009) and dopaminergic- (Chun et al. 2016; Hayashi et al. 2013) neurons, Schwann cells (Faroni et al. 2016) or neuro-glial cells (Miceli et al. 2016; Radtke et al. 2009) at larger quantities, to cure other neurodegenerative diseases too (Figure 4).

In conclusion, lentiviral encoding for erythropoietin (EPO) gene were successfully transduced into mesenchymal stem cells derived from human Wharton's jelly of umbilical cord. The secreted EPO protein could enhance cell differentiation into neural progenitor cell fate following neurosphere induction with neural induction medium. Taken together, the current study provides a rational strategy whereby utilisation of MSCs expressing EPO (MSCEPO) would provide a potential strategy for MSCs differentiation into neural cell fate to achieve a successful cell replacement therapy in future clinical setting involving neurodegenerative diseases.

\section{ACKNOWLEDGEMENTS}

This research was funded by the Deanship of Scientific Research, Jouf University (40/G/03). The authors also acknowledged Cryocord Sdn. Bhd. for providing the human Wharton's Jelly-derived Mesenchymal Stem Cells for the current study. All authors reviewed the manuscript and declare no potential conflicts of interest. Both Mok Pooi Ling and Shirley Ding Suet Lee are equally contributing first authors. Mok Pooi Ling conceived the experimental study design, analyzed the data, and composed the manuscript; Shirley Ding Suet Lee conducted the experiments, composed this manuscript and prepared the figures; Suresh Kumar supported with study design, analyzed, and commented on both data and figures; Mohammed Safwan Ali Khan, Aisha Farhana and Badr Alzahrani analyzed and edited the manuscript. 


\section{REFERENCES}

Alsaeedi, H.A., Koh, A.E., Lam, C., Rashid, M.B.A., Harun, M.H.N., Saleh, M.F.B.M., Teh, S.W., Luu, C.D., Ng, M.H., Isa, H.M., Leow, S.N., Then, K.Y., Bastion, M.C., Mok, P.L., Muthuvenkatachalam, B.S., Samrot, A.V., Swamy, K.B., Nandakumar, J. \& Kumar, S.S. 2019. Dental pulp stem cells therapy overcome photoreceptor cell death and protects the retina in a rat model of sodium iodateinduced retinal degeneration. J. Photochem. Photobiol. B 198: 111561. doi: 10.1016/j.jphotobiol.2019.111561.

Bhutto, I. \& Lutty, G. 2012. Understanding age-related macular degeneration (AMD): Relationships between the photoreceptor/retinal pigment epithelium/Bruch's membrane/choriocapillaris complex. Mol. Aspects Med. 33(4): 295-317. https://doi.org/10.1016/j. mam.2012.04.005.

Borhani-Haghighi, A., Ghodsi, M., Razeghinejad, M.R., Mardani, S., Mardani, M., Nikseresht, A.R., Safari, A. \& Bagheri, M.H. 2012. Erythropoietin for acute multiple sclerosis in patients with optic neuritis as a first demyelination event. Neurosciences (Riyadh) 17: 151-155.

Carelli, S., Giallongo, T., Viaggi, C., Gombalova, Z., Latorre, E., Mazza, M., Vaglini, F., Di Giulio, A.M. \& Gorio, A. 2016. Grafted neural precursors integrate into mouse striatum, differentiate and promote recovery of function through release of erythropoietin in MPTP-treated mice. ASN Neuro 2016: 1-18. doi:10.1177/1759091416676147.

Chun, S.Y., Soker, S., Jang, Y.J., Kwon, T.G. \& Yoo, E.S. 2016. Differentiation of human dental pulp stem cells into dopaminergic neuron-like cells in vitro. J. Korean Med. Sci. 31: 171-177. doi:10.3346/jkms.2016.31.2.171.

Chung, C.S., Fujita, N., Kawahara, N., Yui, S., Nam, E. \& Nishimura, R. 2013. A comparison of neurosphere differentiation potential of canine bone marrow-derived mesenchymal stem cells and adipose-derived mesenchymal stem cells. J. Vet. Med. Sci. 75: 879-886. doi: DN/JST. JSTAGE/jvms/12-0470 [pii].

Chung, H., Lee, H., Lamoke, F., Hrushesky, W.J.M., Wood, P.A. \& Jahng, W.J. 2009. Neuroprotective role of erythropoietin by antiapoptosis in the retina. J. Neurosci. Res. 87: 23652374. doi:10.1002/jnr.22046.

Danielyan, L., Schäfer, R., Schulz, A., Ladewig, T., Lourhmati, A., Buadze, M., Schmitt, A.L., Verleysdonk, S., Kabisch, D., Koeppen, K., Siegel, G., Proksch, B., Kluba, T., Eckert, A., Köhle, C., Schöneberg, T., Northoff, H., Schwab, M. \& Gleiter, C.H. 2009. Survival, neuronlike differentiation and functionality of mesenchymal stem cells in neurotoxic environment: The critical role of erythropoietin. Cell Death Differ. 16: 1599-1614. doi:10.1038/cdd.2009.95.

Ding, S.S.L., Koh, A.E., Suresh, K., Khan, M.S.A., Alzahrani, B. \& Mok, P.L. 2019a. Genetically-modified human mesenchymal stem cells to express erythropoietin enhances differentiation into retinal photoreceptors: An in vitro study. J. Photochem. Photobiol. B 195: 3338.

Ding, S.S.L., Subbiah, S.K., Khan, M.S.A., Farhana, A. \& Mok, P.L. 2019b. Empowering mesenchymal stem cells for ocular degenerative disorders. Int. J. Mol. Sci. 20(7): 1784. doi.org/10.3390/ijms20071784.

Ding, S.L.S., Kumar, S. \& Mok, P.L. 2017. Cellular reparative mechanisms of mesenchymal stem cells for retinal diseases. Int. J. Mol. Sci. 18(8): 1406. doi: 10.3390/ ijms18081406.
Ding, J.D., Johnson, L.V., Herrmann, R., Farsiu, S., Smith, S.G., Groelle, M., Mace, B.E., Sullivan, P., Jamison, J.A., Kelly, U., Harrabi, O., Bollini, S.S., Dilley, J., Kobayashi, D., Kuang, B., Li, W., Pons, J., Lin, J.C. \& Bowes, R.C. 2011. Anti-amyloid therapy protects against retinal pigmented epithelium damage and vision loss in a model of age-related macular degeneration. Proc. Natl. Acad. Sci. USA 108: E279-E287. doi:10.1073/pnas.1100901108.

Eckardt, K.U. \& Kurtz, A. 2005. Regulation of erythropoietin production. Eur. J. Clin. Investig. 35: 13-19. doi:10.1113/ jphysiol.2010.195057.

Faroni, A., Smith, R.J.P., Lu, L. \& Reid, A.J. 2016. Human schwann-like cells derived from adipose-derived mesenchymal stem cells rapidly de-differentiate in the absence of stimulating medium. Eur. J. Neurosci. 43: 417430. doi:10.1111/ejn.13055.

Gupta, N., Liu, J.R., Patel, B., Solomon, D.E., Vaidya, B. \& Gupta, V. 2016. Microfluidics-based 3D cell culture models: Utility in novel drug discovery and delivery research. Bioeng. Transl. Med. 1: 63-81. doi:10.1002/ btm2.10013.

Hassouna, I., Ott, C., Wüstefeld, L., Offen, N., Neher, R.A., Mitkovski, M., Winkler, D., Sperling, S., Fries, L., Goebbels, S., Vreja, I.C., Hagemeyer, N., Dittrich, M., Rossetti, M.F., Kröhnert, K., Hannke, K., Boretius, S., Zeug, A., Höschen, C., Dandekar, T., Dere, E., Neher, E., Rizzoli, S.O., Nave, K.A., Sirén, A.L. \& Ehrenreich, H. 2016. Revisiting adult neurogenesis and the role of erythropoietin for neuronal and oligodendroglial differentiation in the hippocampus. Mol. Psychiatry 21: 1-16. doi:10.1038/mp.2015.212.

Hayashi, T., Wakao, S., Kitada, M., Ose, T., Watabe, H., Kuroda, Y., Mitsunaga, K., Matsuse, D., Shigemoto, T., Ito, A., Ikeda, H., Fukuyama, H., Onoe, H., Tabata, Y. \& Dezawa, M. 2013. Autologous mesenchymal stem cellderived dopaminergic neurons function in parkinsonian macaques. J. Clin. Invest. 123: 272-284. doi:10.1172/ JCI62516.

Ji, H.P., Xiong, Y., Zhang, E.D., Song, W.T., Gao, Z.L., Yao, F., Sun, H., Zhou, R.R. \& Xia, X.B. 2017. Which has more stem-cell characteristics: Müller cells or Müller cells derived from in vivo culture in neurospheres? Am. J. Transl. Res. 9(2): 611-619.

Klassen, H. 2015. Stem cells in clinical trials for treatment of retinal degeneration. Expert. Opin. Biol. Ther. 2598: 1-8. doi:10.1517/14712598.2016.1093110.

Leite, C., Silva, N.T., Mendes, S., Ribeiro, A., De Faria, J.P., Lourenço, T., dos Santos, F., Andrade, P.Z., Cardoso, C.M., Vieira, M., Paiva, A., da Silva, C.L., Cabral, J.M., Relvas, J.B. \& Grãos, M. 2014. Differentiation of human umbilical cord matrix mesenchymal stem cells into neural-like progenitor cells and maturation into an oligodendroglial-like lineage. PLOS ONE 9: e111059. doi:10.1371/journal.pone.0111059.

Leow, S.N., Luu, C.D., Hairul Nizam, M.H., Mok, P.L., Ruhaslizan, R., Wong, H.S., Wan Abdul Halim, W.H., Ng, M.H., Ruszymah, B.H., Chowdhury, S.R., Bastion, M.L. \& Then, K.Y. 2015. Safety and efficacy of human Wharton's jelly-derived mesenchymal stem cells therapy for retinal degeneration. PLOS ONE 10(6): e0128973. doi: 10.1371/journal.pone.0128973.

Li, C.J., Sun, L.Y. \& Pang, C.Y. 2015. Synergistic protection of $\mathrm{N}$-acetylcysteine and ascorbic acid 2-phosphate on human mesenchymal stem cells against mitoptosis, necroptosis and apoptosis. Sci. Rep. 5: 9819. doi:10.1038/srep09819. 
Lv, W., Li, W.Y., Xu, X.Y., Jiang, H. \& Bang, O. 2015. Bone marrow mesenchymal stem cells transplantation promotes the release of endogenous erythropoietin after ischemic stroke. Neural Regen. Res. 10(8): 1265-1270. doi:10.4103/1673-5374.162759.

Ma, K., Fox, L., Shi, G., Shen, J., Liu, Q., Pappas, J.D., Cheng, J. \& Qu, T. 2011. Generation of neural stem cell-like cells from bone marrow-derived human mesenchymal stem cells. Neurol. Res. 33: 1083-1093. doi:10.1179/17431328 11 Y.0000000053.

Miceli, M., Dell'Aversana, C., Russo, R., Rega, C., Cupelli, L., Ruvo, M., Altucci, L. \& Chambery, A. 2016. Secretome profiling of cytokines and growth factors reveals that neuroglial differentiation is associated with the down-regulation of chemokine ligand 2 (MCP-1/CCL2) in amniotic fluid derived-mesenchymal progenitor cells. Proteomics 16: 674-688. doi:10.1002/pmic.201500223.

Mok, P.L., Leow, S.N., Koh, A.E., Mohd Nizam, H.H., Ding, S.L., Luu, C., Ruhaslizan, R., Wong, H.S., Halim, W.H., Ng, M.H., Idrus, R.B., Chowdhury, S.R., Bastion, C.M., Subbiah, S.K., Higuchi, A., Alarfaj, A.A. \& Then, K.Y. 2017. Micro-computed tomography detection of gold nanoparticle-labelled mesenchymal stem cells in the rat subretinal layer. Int. J. Mol. Sci. 18(2): 345. doi: 10.3390/ ijms 18020345 .

Mun-Fun, H., Ferdaos, N., Hamzah, S.N., Ridzuan, N., Hisham, N.A., Abdullah, S., Ramasamy, R., Cheah, P.S., Thilakavathy, K., Yazid, M.N. \& Nordin, N. 2015. Rat full term amniotic fluid harbors highly potent stem cells. Res. Vet. Sci. 102: 89-99. doi:10.1016/j.rvsc.2015.07.010.

Mung, K.L., Tsui, Y.P., Tai, E.W.Y., Chan, Y.S., Shum, D.K.Y. \& Shea, G.K.H. 2016. Rapid and efficient generation of neural progenitors from adult bone marrow stromal cells by hypoxic preconditioning. Stem Cell Res. Ther. 7: 146. doi:10.1186/s13287-016-0409-x.

Ovando-Roche, P., West, E.L., Branch, M.J., Sampson, R.D., Fernando, M., Munro, P., Georgiadis, A., Rizzi, M., Kloc, M., Naeem, A., Ribeiro, J., Smith, A.J., Gonzalez-Cordero, A. \& Ali, R.R. 2018. Use of bioreactors for culturing human retinal organoids improves photoreceptor yields. Stem Cell Res. \& Ther. 9: 156. doi.org/10.1186/s13287018-0907-0.

Portmann-Lanz, C.B., Schoeberlein, A., Portmann, R., Mohr, S., Rollini, P., Sager, R. \& Surbek, D.V. 2010. Turning placenta into brain: Placental mesenchymal stem cells differentiate into neurons and oligodendrocytes. Am. J. Obstet. Gynecol. 202: 294.e1-294.e11.

Radtke, C., Schmitz, B., Spies, M., Kocsis, J.D. \& Vogt, P.M. 2009. Peripheral glial cell differentiation from neurospheres derived from adipose mesenchymal stem cells. Int. J. Dev. Neurosci. 27: 817-823. doi:10.1016/j. ijdevneu.2009.08.006.

Roozafzoon, R., Lashay, A., Vasei, M., Ai, J., Khoshzaban, A., Keshel, S.H., Barabadi, Z. \& Bahrami, H. 2015. Dental pulp stem cells differentiation into retinal ganglion-like cells in a three dimensional network. Biochem. Biophys. Res. Commun. 457: 154-160. doi:10.1016/j.bbrc.2014.12.069.

Schwartz, S.D., Tan, G., Hosseini, H. \& Nagiel, A. 2016. Subretinal transplantation of embryonic stem cellderived retinal pigment epithelium for the treatment of macular degeneration: An assessment at 4 years. Investig. Ophthalmol. Vis. Sci. 57: ORSFc1-ORSFc9. doi:10.1167/ iovs.15-18681.
Shirley Ding, S.L., Leow, S.N., Munisvaradass, R., Koh, E.H., Bastion, M.L.C., Then, K.Y., Kumar, S. \& Mok, P.L. 2016. Revisiting the role of erythropoietin for treatment of ocular disorders. Eye (Lond) 30: 1293-1309. doi:10.1038/ eye.2016.94.

Wyse, R.D., Dunbar, G.L. \& Rossignol, J. 2014. Use of genetically modified mesenchymal stem cells to treat neurodegenerative diseases. Int. J. Mol. Sci. 15: 17191745. doi:10.3390/ijms15021719.

Yang, E., Liu, N., Tang, Y., Hu, Y., Zhang, P., Pan, C., Dong, S., Zhang, Y. \& Tang, Z. 2015. Generation of neurospheres from human adipose-derived stem cells. Biomed. Res. Int. 2015: 743714. doi: 10.1155/2015/743714.

Zhang, D., Zhang, F., Zhang, Y., Gao, X., Li, C., Yang, N. \& Cao, K. 2007. Combining erythropoietin infusion with intramyocardial delivery of bone marrow cells is more effective for cardiac repair. Transpl. Int. 20: 174-183. doi:10.1111/j.1432-2277.2006.00407.x.

Zhou, Y., Chen, H., Li, H. \& Wu, Y. 2016. 3D culture increases pluripotent gene expression in mesenchymal stem cells through relaxation of cytoskeleton tension. J. Cell Mol. Med. 21: 1073-1084. doi:10.1111/jcmm. 12946.

Mok Pooi Ling*, Aisha Farhana \& Badr Alzahrani

Department of Clinical Laboratory Sciences

College of Applied Medical Sciences

Jouf University, Sakaka, P.O. Box 2014

Aljouf Province

Saudi Arabia

Mok Pooi Ling*, Shirley Ding Suet Lee \& Mohammed Safwan Ali Khan

Department of Biomedical Science

Faculty of Medicine and Health Sciences

Universiti Putra Malaysia

43400 UPM Serdang, Selangor Darul Ehsan

Malaysia

Mok Pooi Ling* \& Suresh Kumar

Genetics and Regenerative Medicine Research Centre

Universiti Putra Malaysia

43400 UPM Serdang, Selangor Darul Ehsan

Malaysia

Suresh Kumar

Department of Medical Microbiology and Parasitology

Faculty of Medicine and Health Sciences

Universiti Putra Malaysia

43400 UPM Serdang, Selangor Darul Ehsan

Malaysia

Suresh Kumar

Institute of Bioscience

Universiti Putra Malaysia

43400 UPM Serdang, Selangor Darul Ehsan

Malaysia

*Corresponding author; email: rachelmok2005@gmail.com

Received: 6 September 2019

Accepted: 7 October 2019 